\title{
Hungarian Participation in the EU-Led African Military Operations
}

\author{
János BESENYÖ ${ }^{1}$
}

\begin{abstract}
Africa is a high priority region to the European Union. Therefore, the European Union launched independent missions in the unstable regions of the African continent regularly since 2003, in order to restraint and eliminate local conflicts and prepare local armed forces for mission. Hungary was involved in a wide range of tasks in recent years from June 2005. We contributed to the success of these missions, our soldiers served on the highest respectable level among others in the Darfur, Congo, Chadian, Somali and Mali operations as well as in the elimination of piracy in this region. After all, it is likely that the European Union will continuously count on our country's participation in its peacesupporting missions. In the study I would like to present nine major operations, and the ultimately cancelled Libyan mission. I detail the case-specific objectives and implementation through first-hand experience, which was gained during my deployment. As far as Hungary is concerned, I wish to demonstrate the Hungarian soldiers' admirable work during these missions, besides, I would like to concentrate on the background and conditions of our participation.
\end{abstract}

Keywords: European Union, Africa, Congo, Darfur, Chad, Naval Operation, Somalia, Mali, Libya, Central Africa, Hungary, peacekeeping, piracy, humanitarian activity, military training

\section{The EU Operation "Artemis"}

The EU Operation “Artemis” (DRC Artemis) [1] was the EU’s first fully independent mission in the African continent, which was carried out without NATO support between the $12^{\text {th }}$ of June and the $07^{\text {th }}$ of September 2003. Although the mission operated under the aegis of the EU, the management and leadership were clearly in French hands.

Starting the operation was a need, since bloody conflict between the Hema and Lendu tribal militias broke out in the Democratic Republic of the Congo's Ituri province with a total population of 4.5 million. Soon, other nationalities also got involved in the clashes. ${ }^{2}$

The UN forces in Congo (United Nations Mission in the Democratic Republic of the Congo-MONUC) were unable to bring the clashes under control, therefore the UN Secretary General on the $19^{\text {th }}$ of May called the European Union-as it had strategic interest in Africa - on the implementation of a limited operation, which was adopted by the UN Security Council Resolution No. 1484 on 30 May with the following mandate: [2]

- enforcing stability in Bunia by a limited military operation, securing the airport;

\footnotetext{
$1 \quad$ Ph.D., Colonel, Head of a Research Section in the Hungarian Ministry of Defence; e-mail: besenyo.janos@gmail.com

2 The city had approximately 300,000 inhabitants, who belonged to the Alur, Hema, Lendu, Ngiti, Bira and Ndo-Okebo tribes. [1]
} 
- performing security tasks (facilitating the solution of the Hema-Lendu conflict);

- humanitarian activities, protecting refugees and civilians;

- supporting operation of MONUC, protecting UN operatives and facilities.

Originally, the EU operation was an Interim Emergency Multinational Force. It was designed for three months and for a limited area of operations, until the UN Mission in the Democratic Republic of the Congo takes over control of the province. Seventeen countries participated in the French-led mission with 2,548 personnel. [3: 59] [4] [5] The EU Operation "Artemis" command was located in Paris, led by the French Lieutenant General Bruno Neveux. The strategic headquarters worked in the Ugandan Entebbe city, commanded by the French Major General Jean-Paul Thonier, while the "Outpost Command Centre” was set up in the operational field in Bunia. French air force units and civilian firms' Lockheed C-5 and Antonov 124 aircrafts provided the transportation of troops and logistics supply between Uganda and Bunia. The first European peacekeepers arrived in Bunia on the $6^{\text {th }}$ of June, where the airport was secured without any problems, the troops could begin collecting their weaponry. Up to the $8^{\text {th }}$ of July, the broad-mandated, well trained and equipped European units cleaned the city from armed groups, where life returned to normal. By the end of July, they also managed to stabilize the security situation in the suburbs. Meanwhile, the UN raised the amount of its employees to MONUC by 10,800 personnel and began securing the previously Artemis-guarded areas. [6] Withdrawal of European troops began in the middle of August and ended on the $7^{\text {th }}$ of September. On the $25^{\text {th }}$ of September they mopped up the headquarters in Uganda.

The balance of mission was definitely positive, which encouraged the EU for further participation in the continent's processes. ${ }^{3}$

Lieutenant Colonel János Tomolya served in the mission headquarters in Paris as chief military personnel officer. Since he graduated from the French military academy, he was the most likely to be chosen for the French-Hungarian negotiations. Originally, Hungary did not intend to take part in the mission, but the political leadership believed that participating in the Congo operation could be beneficial as an applicant for EU membership. Finally, the appointed officer hadn't been deployed to operational field, but with national limitations to the headquarters in Paris.

\section{EU Support to AMIS (Darfur)}

The EU support to African Union's enhanced Mission to Sudan (AMIS/Darfur) operation [7] —between June 2005 and December 2007—was the next African mission, where Hungarian soldiers were sent. The mission was preceded by a conflict between nomads (Arabs) and agricultural (black) tribes in February 2003, the escalation of which was accelerated by the Sudanese government-paid Arab militias' activities. [8] Fulfilling their ambitions and in reaction to the international pressure, the AU launched a peace-support operation (AMIS) in the region, which had to deal with a wide range of problems from the beginning. Initially,

In spite of this, the mission faced with such problems like strategic air transport capabilities or the inefficient logistics supply. 
the EU only provided financial and logistical support to AMIS, but later the support grown so diverse, they provided help through a joint support operation, [9: 117-118] which received a mandate in the following activities: [7]

- operating and supporting AMIS II;

- general and specialized training of African soldiers;

- managing and implementing tactical-strategic air transports;

- logistics supply, consulting 2012-advisory group;

- police assistance;

- participating in humanitarian programs.

From the beginning of the mission Hungary has been among those, who offered observers for the operation, as the political leadership rightly assessed that Africa is a major priority for the EU foreign policy. Besides the crisis in Sudan, the humanitarian disaster in Darfur made enormous impact on the world press. World-wide political support helped the work of organizations, searching for solution, through which our participation could generate great advantages in foreign policy. ${ }^{4}$

Leaders of the Hungarian Defence Forces appointed Major Ferenc Kajári to AMIS as an unarmed military observer from June 2004 to June 2005, who served as chief reconnaissance officer in one of the camps (Kabkabiya). The Major carried out classic peacekeeping/observer tasks, within the framework of which he took part in the everyday operation of camps, went patrolling and investigated ceasefire violations. Besides he endeavoured to be a neutral party and build a good relationship between the conflicting parties. The African Union's military leadership was so pleased with Major Kajári’s work, they asked the European Union for further deployment of Hungarian troops. Thereby I got an opportunity to serve in El-Fasher headquarters in June 2005 as an (logistics) advisor. I've spent only six months in the mission, during which—as the camp supply department Deputy Commander-I was responsible for the nearly 12,500 deployed soldiers and police units (food, air and ground transportation, fuel, water security, and the operation and fire protection of the camps). Due to the sharp deterioration of the security situation in December I had been recalled from the mission, additionally Hungary withdrew its earlier offers to make further Hungarian soldiers serve in Darfur.

\section{EU Advisory and Support Mission in the Democratic Republic of the Congo}

During the operation, the Africans' attitude toward us "white” advisors was challenging. On the basis of the misconceived "African ownership" they asked financial, logistical support and a lot of work from the donors without taking any of our advice on the deficiencies. Almost every aspect of our supply (food, accommodation, hygiene, provision of drinking

$4 \quad$ This is proven by the fact that one of the leaders of the EU mentioned to a member of the Hungarian EU representation in Brussels that Hungary was the only one among accession countries, that offered an observer which is a good breakaway opportunity among the member countries. According to him, the offers to Darfur mission is a — not only, but important—sign for the countries' readiness to respond, which helps the EU in crisis management, active and responsible participation in humanitarian disasters. 
water etc.) was problematic and it didn’t meet any of a common norm either. Despite all this, we earned the recognition of our work from the AU, and the EU as well. Instead, at home it was decided that we should take part rather in the European Union Security Sector Reform Mission in the Democratic Republic of the Congo (EUSEC RD Congo) which was launched on $2^{\text {nd }}$ May 2005. Hungarian soldiers still serve in this mission. [9] Following the peace agreement, which ended the second Congolese civil war, an official request for peacekeeping arrived from the African country. Answering this, the Hungarian leadership decided to participate-with a limited amount of personnel-in the Congolese security sector reform. The mandate of "EUSEC RD Congo" lasted for one year, with a budget of only $€ 1.6$ million. The operation was given a mandate in the following activities: [10]

- supporting Congolese government;

- supporting the security and cooperation of the countries, which are surrounding the African Great Lakes;

- supporting the reform in the administration and financial system of the military, transforming the Defence Sector;

- cooperating with the European Union Police Mission in Kinshasa (the Democratic Republic of the Congo), peacekeeping mission (EUPOL Kinshasa is aiming to reform the security of the Democratic Republic of the Congo);

- humanitarian activities.

From the beginning of the mission, the Hungarian Defence Forces was represented. First by one, later by three soldiers. However, the lack of officers who were able to communicate in English and French created difficulty in deployment, so Lieutenant Colonel István Papp was recalled from pension for service in Kinshasa, who then was closely involved in setting up the mission. [11] This deficiency remained in the later stages, ${ }^{5}$ so the majority of officers were not sent in the Congo on a yearly mission, but for at least two or three years. Colonel Sándor Nagy was also a senior officer, who returned home after four years. Following the respectable work of Colonel Papp, the EU asked another flag officer for the position of financial officer, and for this, Major Zsigmond Csajági was deployed.

The main duties of the two flag officers were linked to the military transition. At first, they took part in the registration and check of the military personnel. Additionally, another Hungarian officer arrived, who was responsible for the operation's IT tasks.

Meanwhile, Lieutenant Colonel Papp left the mission, so that a system evolved where Hungary regularly sent two military advisers to the mission. In the last period this commitment decreased by 1 personnel/mission, since we weren’t able to fill both positions at the same time. By the summer of 2015, eleven Hungarian officers and flag officers served in the mission.

Since the registration process could not be controlled from the capital, involved personnel spent most of their time in several camps on the operational field. It was also important because some of the local military leaders caused serious financial damage to the country with different types of fraud (larger amount of staff have been reported, they promoted people for financial rewards etc.).

Teaching French would be efficient for our further involvement in Africa; unless this language-knowledge, operation in North- and Middle-Africa is nearly impossible. 
Obviously, the European advisors' activities hurt the interests of several military leaders and warlords. Thereby Europeans received serious threats more than once and their lives were in danger, as well. Hungarian experts worked as consultants in the Defence Secretary's Office, Army General Staff, Joint Operational Committee and in the Committee for disarmament, demobilization, reintegration of former combatants, which was also responsible for decommissioning child soldiers. They also took part in the transformation of military structure, the Congolese army's internal control on financial and human resources, and the training of Congolese officers and flag officers.

In addition, they played an important role in disarmament and humanitarian programs. These projects, however, could not be completed in a year, so each year the mandate of the EU mission was extended again and again, and the personnel was increased to 60 people instead of the starter 8 officers. The annual budget reached 10.9 million Euros. [9: 107] Up to now, the EUSEC carries out major tasks in the field of logistics, supply systems, the operation of the military preparation and training. Over the past few years, the mission provided a few tangible results, however, it is considered more successful than the UN operation (MONUSCO) with its 20,000 personnel, both internationally and in the Congo.

Although very good circumstances were provided for advisers at the Kinshasa headquarters, during fieldwork, often the most basic tools were missing. The complicated and bureaucratic system of the EU made operations difficult, which could easily extend the execution of an operation by a year. [12: 350-351] In the meantime, the mission set up offices in several other locations outside the capital, leaving only one Hungarian soldier at the headquarters. The others performed service in Kisangani, Bukavu, Goma, Bunia and elsewhere, where 18 integrated brigades were set up by the former government forces and opponent militias.

The "rural" services were more dangerous in comparison to the duty in the capital because of the weaker influence of the Government, so soldiers earned special hazard allowances as a compensation. Getting used to very different climatic conditions meant particular problems for the Hungarian soldiers, as well as daily infections such as malaria, Ebola, dysentery, typhoid or cholera. Through the past ten years in the ongoing operation, ten Hungarian officers served in the mission. The shifts were sometimes problematic but we were able to maintain the required amount of Hungarian participation.

\section{European Union Military Operation in the Democratic Republic of the Congo}

Hungarian soldiers also undertook other operations in Congo, such as ensuring the Congolese parliamentary elections in the frame work of the EUFOR RD Congo. The operation was established by the UNSC 1671 decision, which was launched following the UN and the Congolese Government's request in 2006. The tasks started on $12^{\text {th }}$ June 2006 and lasted until $30^{\text {th }}$ November 2006. Some of the EU member states did not support the Franco-German-led operation and considered it unnecessary, thus they were not—or only limitedly—involved. ${ }^{6}$ [13: 99]

Javier Solana met with the Defence Ministers of the reluctant countries on $22^{\text {nd }}$ February, and managed to convince them in participating in the operation. 
In the framework of the mission, the local elections in June were secured by 21 European member states, Turkey (with 2,275 soldiers and police officers) and the USD 20.9 million budget. [9: 111] According to the former Hungarian offers, logistics and HR professionals were sent instead of combat troops. ${ }^{7}$ [14: 117]

The EUFOR RD Congo received a mandate in the followings: [15]

- securing the Congolese parliamentary elections in accordance with the UNSCR 1671 decision;

- supporting the operation of MONUC;

- supporting the Congolese Government;

- implementing security tasks;

- protection of civilians;

- securing the airport in Kinshasa;

- humanitarian activities.

The mission was led by the German Lieutenant General Karlheinz Viereck and the French Major General Christian Damay. Operations related to planning and coordination were handled at mission headquarters in Potsdam, ${ }^{8}[16]$ while the implementation of the daily activities was carried out in the airport in Kinshasa N'Djilli Operation Headquarters (OHQ) (1,075 people). Most of the mission forces (1,200 people) were deployed to Gabon's capital, Libreville. Had an attack occurred in Kinshasa, they could easily interfere from Libreville. According to the plans, a French battalion (400 people) strategic reserve force was established in Europe. Although, eventually actual deployment of this reserve didn't take place. [13: 102] [17: 363-364] Due to certain reasons, the three Hungarian officers were sent with national restrictions. They served in the mission headquarters in Potsdam, despite the fact that the EU's military leadership planned them in the area of operations. Hungarian flag officers carried out the tasks related to the logistics of the mission and performance of personnel.

In addition to the fact that some of the European states refused to send troops to the operation, cooperation between EUFOR RD Congo and MONUC was also problematic. They faced certain managerial and logistical challenges (lack of airlift capacity), but the operation finally reached its goal as both rounds of the elections could take place without any problems, so according to the plans, EUFOR RD was completed on $30^{\text {th }}$ November 2006. However, some teams were withdrawn only in December and the EU headquarters in Potsdam was mopped up in February, 2007.

\section{EU Military Operation in Eastern Chad and North-Eastern Central African Republic (EUFOR Tchad/RCA)}

The next operation in which Hungarian soldiers took part was the EU Military Operation in Eastern Chad and North-Eastern Central African Republic mission. The mission was

\footnotetext{
7 In this case, we were not the only nation that refused to send "combat" troops in the operation, several other countries have decided to take part in the operation with only a few staff officers with national restrictions.

8 Namely the Henning von Tresckow barrack in Deltow, near Potsdam. One of the EU's OHQ with multinational capabilities (originally five nations, more if needed).
} 
established in reaction to the conflict in western Sudan (Darfur) and its regional impactsmainly on Chad and the Central African Republic - and the mentioned countries' unstable internal political situation. The operation lasted from $28^{\text {th }}$ January 2008 until $15^{\text {th }}$ March 2009. Four (personnel, logistics and medical) officers were sent to the mission. The operation received a mandate in the following activities: [18]

- guarantying regional security, cooperation with the bodies of the UN, Chad, Central African Republic;

- patrolling;

- protecting civilians and refugees, reintegrating them, securing international civilians;

- delivering humanitarian aids.

Two headquarters had been established based on past experience. Strategic Command in Paris ${ }^{9}$ [19] was led by Irish Lieutenant General Patrick Nash, while the operational headquarters in Chad (in N'djamena and Abechi) worked under the guidance of French Major General Jean-Philippe Ganascia. The three battalions were deployed to Iri, Forchana and Goz Beida and cities, while a company-sized unit served in the Central African Birao. 23 EU member states as well as Albania, Croatia and Russia ${ }^{10}$ [14: 120] were involved in the mission with—in total—3,396 people. [17: 380]

Similarly, to other missions, EU did not use any NATO equipment or assistance. ${ }^{11}$ [9: 110] On the other hand they cooperated very well with the organization, using the previous experience from Operation EUFOR RD Congo. Unlike the previous short-term and limited operations, the EUFOR CHAD operated with a budget of EUR 119.6 million, moreover it was not only in Chad for over fifteen months, but played a significant role in the Central African Republic, as well. [14: 118] Actually, it was the “trial run” for EU's long-term operations. Despite the limited mandate and several difficulties (logistical problems, slow mobilization, high OHQ accommodation costs), it was performed successfully. [12: 398-399] Through this, the EU enhanced 'Europeanisation' of peace operations in Africa, and it did not just become equal with the African Union, but it surpassed the other regional organization's level of success.

The Hungarian leadership_-as a result of former experience of the Congolese operations - contributed to the work at operational field. Major Ferenc Nagy carried out transport coordination and several planning tasks in Chad. [20] Command of the mission assessed the work of Hungarian officers positively, which was partly due to the work of Major Antal Csaba Kiss doctor, who prepared an analysis on the health risk of the mission, which was a great help for the armed forces of Chad..$^{12}$ All officers mentioned that cooperation with local people and the French soldiers was problematic since-despite the fact that English was

9 Namely EU’s Mont Valérien OHQ in Paris, Saint-Cloud. One of the EU’s OHQ with multinational capabilities (originally five nations, more if needed).

10 Participation of Russia was greatly important as the EU still didn't have the needed airlift capability, thus the success of the mission was highly dependent on the Russian helicopters.

11 Berlin Plus mechanism.

12 This document was so successful that when the EU planned to launch a mission in Libya, the HDF was asked to make the Major or some other medical officers write the health-risk analysis. 
the official language - the majority spoke only French and interpreters weren’t continuously provided.

\section{European Union Naval Force Somalia. Operation Atalanta}

The EU NAVFOR Atalanta/EU Naval Operation in the Somali Republic was established by the UN Security Council 1816 resolution on the $2^{\text {nd }}$ June, 2008. Receiving one of the greatest attention among EU missions, it is currently operating on the Red Sea, Gulf of Aden and the Indian Ocean. [21] As an indicator of the mission we could mention piracy-generated security [22] [23] and world economic issues. ${ }^{13}$ [24] The mission operated with approximately 20 crafts, that -in cooperation with regional organizations (UN, NATO) and other national contributions (USA, Russia, China, India, Japan, South-Africa)—controlled 3.7 million square meters of the ocean. The operation received a mandate in the following activities: [14: 121]

- supporting the EU's CSDP;

- combatting piracy, securing trade routes, protection of civilian ships;

- escorting ships of UN World Food Program and other humanitarian convoys;

- supporting the operation of AU's mission in Somalia (AMISOM);

- supervision of fishing in the Somalian shores.

The British-led HQ of the mission (1,400 personnel) was located in Great-Britain, Northwood, ${ }^{14}$ [9: 113] while the convoy's "temporary" base port works was in Djibouti. The average annual budget of the operation was 8.3 million Euros, charged to the ATHENA mechanism. [25] Through trade routes patrols and the supervision of civilian commercial ships' convoy routes, effective cooperation was established with countries in the region (Madagascar, Kenya, Somalia, Djibouti, India, Yemen, Mozambique etc.), and with various civil and professional organizations (shipping, insurance companies), too. Thereby they could act in a more coordinated and more effective way against pirates.

Although the activities of the mission were declared successful, the EU doctrine against the pirates was only published two and a half years after the commencement. Additionally, it was misinterpreted by several member states. Besides, the operation still does not have sufficient intelligence, enough helicopters suitable for patrol, efficient medical insurance and tankers. [12: 456-460] A similar problem is the lack of unified regulations against piracy. Several member states are freeing captured pirates, who are about to carry out further attacks. The fact, that its mandate was extended until 12 December 2016 demonstrates the importance of the operation.

Hungary joined the mission at the beginning of the operation, where three IT Non-commissioned officers were sent with national restrictions. However, this was not a problem compared to the past, since the non-commissioned officers served at the Northwood headquarters and needn't go to the area of operations. Their duty was the registration of

\footnotetext{
13 According to a research of the non-profit One Earth Future Foundation (2010) this amount added up to approximately $7-12$ billion dollars.

14 The all-time commanders' stay in the area of maritime operations in the marine convoy flagship.
} 
merchant vessels on a special website ("Mercury”), their track and support if needed. Thus, they were in daily contact with not only the Navy but also with civil shipping companies. [26] Merchant ships who have registered on the website were gathered in a group with the EU NAVFOR units and went together to the dangerous waters so that they received protection from pirates. The Hungarian non-commissioned officers served in yearly shifts until 2010, when Hungarian military contribution was withdrawn.

\section{European Union Training Mission—Somalia (EUTM-S)}

Later, when the EU invited Hungary to another operation, the idea of sending a special-force unit emerged but finally it was not realized. In replacement, we took our share in the EU Training Mission in Somalia (EUTM Somalia), which began its operation on 10 April 2010 and lasted until December 2016 with the following mandate: [27]

- supporting the implementation of the Djibouti Agreement;

- support for the Temporary Federal Government and government organizations,

- enhancing the operation of AMISOM;

- training Somali government soldiers on the basis of UNSC Resolution No.1872.

The Spanish-led small (125 people) mission worked first time in Uganda where on an annual basis 3,600 Somali soldiers were trained. In December 2013, it moved to Mogadishu, where the headquarters was established at the international airport, while the train continued on Jazeera base. The mission had an annual budget of 11.6 million Euros, which provided the operation of a liaison office in Nairobi as well as a support group in Brussels. In the operation, in addition to the company and battalion commanders, lower ranked leaders, trainers and specialists (officers, non-commissioned officers) were trained, while the Ugandan Army was responsible for the training of the ordinary soldiers. [28] The Somalis were trained in the field of infantry, military police, civil-military cooperation, mechanics and intelligence. In addition, they also acquired knowledge in human rights and humanitarian tasks. At the same time, the mission provided advisors assigned to the Somali Ministry of Defence and General Staff who are also involved in the Somali army reform.

Our country was involved in the operation from the beginning, in which three lawyer officers were sent per a shift. The officer started his duty six week before his deployment in Brussels, where he carried out the preparation of documents regulating the operation. Later, he stayed in Kampala, in the mission headquarters. Trainers were placed in the tent camp of Bihanga, western Uganda. The training was performed by mixed nationality groups accompanying Ugandan soldiers who were responsible for the daily activities of Somalis. Hungarians formed a group with the Germans. Due to their similar readiness and mentality, this group was among the most successful ones. [29] [30]

The first group drew up the rules and guidelines for the next deployed units. Hungarians were responsible for the non-commissioned officers' training, which was conducted six times a week for four months. Theoretical and practical training took place twice a day, exams were written weekly. Hungarian trainers held this system-with minimal changes-in Somalia, too. The training was held in Somali language, so that Hungarians were forced to use interpreters. Breaking with the past trends, our soldiers had no national limitations in this mission, 
they arrived with small arms, thus they were able to defend themselves. Although some very dangerous situations occurred, Hungarian soldiers didn't need to use their weaponry. During the mission, Hungarian soldiers worked under Spartan conditions in Uganda. They lived in tents. They received better conditions in Mogadishu. So far 18 Hungarian soldiers participated in the operation. Although the mission was engaged in small and limited activities, its effectiveness was indisputable. ${ }^{15}$

\section{EU Military Operation in Support of Humanitarian Assistance Operations in Libya}

Hungarian trainers were already in Uganda on $1^{\text {st }}$ April 2011 when a recent mission of the European Union, the Libyan Operations (EUFOR Libya) started. Its basic task was to support humanitarian organizations and civilian population in the civil war-torn Libya by various activities (convoy escorts, medical insurance). Operational plans were made for these tasks; however, no actual request was received from humanitarian organizations, moreover, European states had different opinion on launching the mission. ${ }^{16}$ [31]

The mission had a budget of EUR 8 million, in spite of this, just the 110-strong preparatory staff was set up in Rome, the actual process had not been launched. The EUFOR Libya was given a mandate for the following activities: [12: 425-426]

- protecting Libyan civilians, securing their evacuation;

- creating safe living conditions during the conflict;

- support the work of humanitarian organizations operating in Libya.

The preparatory staff wrote four drafts for the Libyan operations, which covered all of the previously planned tasks. The four plans required four health insurance plans as well. Lieutenant Colonel dr. Tamás Bognár was involved in the preparation process, who was responsible for preventive medical activities and the health risk assessment, as well. He was replaced by Lieutenant Zita Makrai, who continued to carry on the Lieutenant Colonel's duties. At first, Lieutenant Colonel Bognár was sent with national restrictions to EUFOR, but following the request of EU, national limitations were released and Lieutenant Colonel Bognár could travel to the area of operations in Libya. [32]

The two Hungarian officers had double duties. On the one hand they were involved in health planning tasks, which means that they had to organize health care in accordance with the operational plans, thereby ensure that injured personnel receive the required treatment in time. The second task was preventive care, in the framework of which, they prepared mission participants for Libyan health conditions. Although the operation hadn't start, risk analysis and other health programs — carried out by the Hungarian staff-were awarded with widespread recognition of the Hungarian military health care.

15 Recruiting and integration of Somalis to the Somalian army has nothing in common with the EUTM SOMALIA personnel, due to this fact a very limited feedback came from the results of the training.

16 Some of the European countries did not participate coordinated in the EU operation, but according to their own interests in NATO operations against Libya played a role. Thus, the EU was not capable of effective independent operation in the Libyan conflict. Therefore, several experts mentioned the operation as "an April joke”. 


\section{EU Training Mission in Mali (EUTM Mali)}

As a result of the Libyan civil war, thousands of formerly Gaddafi-linked Tuaregs returned to Mali, where they burst-out the centuries-old conflict and proclaimed the Azawad, the independent state of their own. Since radical Islamic terrorist organizations (AQIM, Mujan, Ansar Dine) joined the conflict, an international coalition was formed (first involving the French and the EU, later also the AU and the UN) and ousted radicals. [33]

Following, the UN-EU joint mission, the MINUSMA was established. On $18^{\text {th }}$ February 2013, the French-led, 580-strong EU Training Mission in Mali replaced its mandate. It was responsible for the preparation of specified units of the reorganized Malian army. The Council of the European Union defined a 15-month long duration for the mission, run by 23-member countries on a budget of 12.3 million Euros in 2014. On 15 $5^{\text {th }}$ April 2016 it was extended until the $18^{\text {th }}$ of May, with a budget of 23 million Euros and the following mandate: [34]

- according to the declarations of the Mali National Committee on $29^{\text {th }}$ January 2013, enhancing the restoration of constitutional order;

- restoring and securing the Western-African state's statehood, territorial integrity and sovereignty;

- repelling international terrorist organizations and organized crime;

- training the newly-organized Malian Army units;

- advisory tasks related to the reconstruction and employment of the Malian Army.

Headquarters of the mission is located in Bamako, while the training centre operates in Koulikoro, $60 \mathrm{~km}$ away from the capital. European policymakers declared in the first days that personnel of the EUTM MALI won't participate in combat operations and they keep to this record ever since. [35]

Hungary was among the first who offered soldiers, according to the Government's decision to contribute with 15 (during replacement period up to 30) personnel. A liaison officer, six medical trainers and three soldiers belonged to the first group, who travelled in March and April 2013. The liaison officer served at the headquarters in Bamako. The medical staff worked in the German-Austrian field hospital, while the six infantry soldiers-belonging to the $\mathrm{MH} 5^{\text {th }}$ Istvan Bocskai Infantry Brigade, 5/24. Gergely Bornemissza Reconnaissance Battalion-were deployed to Koulikoro to train the snipers of the Malian army.

The first two battalions of the Hungarian soldiers participated in a ten-week training. In addition to the training, they made an English-language preparatory document, on the basis of which the next, Portugal staff continued their duty. [36] In the further period of the mission, only the liaison officers and medical staff remained in Mali. As the EU extended the mandate of the mission we sent out new trainers, who-in cooperation with the Portuguese-carried out the training of Malian snipers. Hungarian soldiers have been sent out without national restrictions, using their own weapons. African conditions, the relatively short and busy training period, weaknesses in logistic support, monotony in supply meant the biggest challenge for Hungarians. Besides, the official language of the mission was French, what was rarely spoken among Hungarian soldiers. Up to now, sixteen Hungarian soldiers served in the mission. 


\section{European Union Military Operation in the Central African Republic (EUFOR RCA)}

Invitation to take part in the European Union operation in the Republic of Central Africa (EUFOR RCA) [37] was launched during the operation in Mali. The EUFOR RCA was launched on $10^{\text {th }}$ February 2014 by the Council Decision 73/2014/CFSP. EUFOR RCA reached full operational capability on $15^{\text {th }}$ June 2014 . It's end was planned for $15^{\text {th }}$ December 2014 by the UN Security Council in Decision no. 2181 (2014), which was later extended until 15 March 2015 with the following mandate: [38]

- EUFOR RCA participates in the stabilization and securing the situation in Bangui, until this task is transferred to the supervision of the AU operation (MISCA);

- protection of the civilian population, improving their living conditions, ensuring the operation of humanitarian aid;

- support the MINUSCA mission until it reaches full operational capability.

Under the guidance of Major General Philippe Pontičs, strategic command was located in Larissa (Greece), while the operation headquarters (led first by Brigadier General Thierry Lion, eight months later by Brigadier General Jean-Marc Bacquet) operated in Bangui. The EU approved 25.9 million Euros as operation costs, which later was increased by 5.7 million. The EUFOR RCA (mainly included French personnel of the total 750 people) occupied the M'Poko airport in Bangu on the $30^{\text {th }}$ of April. Later, step-bystep, in cooperation with the French "Operation Sangaris”, they shrivelled armed groups from the capital. Part of the mission's activities were transferred to the new EU advisory mission, the Brigadier General Dominique Lauge-led EUMAM RCA (with a budget of 7.9 million Euros), which concentrated on the reorganization and training of the Central African armed forces. [39]

According to the Hungarian Government's decision, 6 staff officers (during replacement period up to 12 people) were deployed partly to the mission's operation headquarters and partly in the operation field headquarters in the capital city of the Republic of Central Africa. Their mandate in the EUFOR RCA lasted until the previously defined operation's mandate, but not longer than $15^{\text {th }}$ March 2015. Actually, three staff officers were sent to the headquarters. Colonel Vekerdy, who played a significant role in the operations area, ended his service on $13^{\text {th }}$ March 2015.

\section{EUNAVFOR MED Operation Sophia}

EUNAVFOR MED was launched in May 2015, [40] in reaction to the overwhelming flow of migrants, who tried desperately to reach European shores through the Mediterranean Sea. Although, the mandate of the mission until 2015 September was primarily reconnaissance and patrolling of the central Mediterranean, in accordance with the common security and defence policy of the EU, it was supplemented by countering human smuggling from Northern Africa, contributing to the implementation of the UN arms embargo on the high seas off the coast of Libya, [41] as well as training of the Libyan Navy Coast 
Guard and the Libyan Navy. ${ }^{17}$ [42] Following the expansion of the mandate, the mission had been renamed EUNAVFOR MED Operation Sophia. Its licenses include intercepting, scanning, impounding and diverting ships of human smuggler units on international waters.

Since January 2016 to November 2016, the operation saved more than 110 thousand people, who departed on insufficient fishing boats, longing for a miracle to reach Europe. [41] According to the estimates of the European External Action Service (EEAS) operation Sophia's activities resulted in 99 suspected smugglers and 337 boats were removed from criminal organizations' set of tools. [43] So far, 25-member states are represented in the mission, which has an ongoing mandate until 27th July 2017. [39: Art. 11] The common costs of the mission, financed by the Member States, amount to EUR 11.82 million for the one-year mandate. [44]

In November 2016, the HQ operated with 159 people, of which 99 were coming from Italy and 60 from the other Member States (Belgium, Bulgaria, Cyprus, the Czech Republic, Estonia, Finland, France, Germany, Greece, Hungary, Latvia, Lithuania, Malta, the Netherlands, Poland, Slovenia, Spain, Sweden, the United Kingdom). [45] Hungary contributed with three senior officers, who were responsible for planning, organizing and synchronizing information operations and aviation activities with the applied "conventional” military assets. [4]

\section{Conclusion}

The current EU operations show that the African continent is not indifferent for the EU and the regional organization definitely wants to take part in addressing African conflicts, which are influencing the security of Europe at several levels, as well. Out of the 29 operations of CSDP, 16 was carried out in Africa. This conclusion could be also based on the fact that since 2008, the EU participated only in African operations. However, it seems that a significant amount of the member countries refuses to undertake serious role in these operations, so it is likely that they will continue to participate with limited mandates. Furthermore, according to recent experience, the EU doesn't wish to take part in peace enforcement in the African continent, rather in peace support operations (such as training and advising).

Hungary is among the top ten-member countries considering the amount of deployed personnel to EU missions, but not to Africa, rather to the Balkan. ${ }^{18}$ Although Hungary isn't "a key player" in the black continent and in previous years the majority of the Hungarian political and military leadership was sceptical about our involvement in African missions, it is increasingly clear that we can't exclude ourselves from the African events. This is indicated by the change in the Hungarian foreign affairs priorities, the "opening to the South" process. Therefore, it would be worthwhile to process our experiences in Africa, on the basis of which preparations should began for a possible operation. Simultaneously removing

17 Two ships of the deployed units (San Giorgio and Rotterdam) welcomed 78 Libyan trainees of the Libyan Navy Coast Guard in 2016, in order to improve security of the Libyan territorial waters and enhance search and rescue activities in Libyan territorial waters, as well.

18 Hungary deployed 304 personnel to the EUFOR mission in the Balkans. Additionally, we also serve in 21 individual positions. 
existing shortcomings (French-knowledge) should take place. It is clear that there are several areas (intelligence, reconnaissance, logistics, water purification and health), where the EU is struggling with shortages and where the EU appreciates Hungarian participation (even despite the relatively small number of employees!). ${ }^{19}$ Therefore, these areas are proposed to be further developed in accordance with our possible future African engagement.

\section{References}

[1] TOMOLYA J.: Operation “Artemis”: The First Autonomous EU-led Operation. AARMS, 141 (2015), 121-132. www.uni-nke.hu/document/uni-nke-hu/aarms-2015-1-tomolya. original.pdf (Downloaded: 29.03.2017)

[2] EEAS: ARTEMIS/DRC. www.eeas.europa.eu/csdp/missions-and-operations/artemis-drc/ index_en.htm (Downloaded: 29.03.2017)

[3] RODT, A. P.: The European Union and Military Conflict Management: Defining, Evaluating and Achieving Success. London: Routledge, 2014.

[4] SODER, K.: EU crisis management: an assessment of member states' contributions and positions. www.ies.be/files/Soder-D1-NOT4WEB.pdf (Downloaded: 29.03.2017)

[5] TÜRKE A. I.: The Operation Artemis in the Democratic Republic of Congo, CERPESC - Sorbonne. www.academia.edu/9502774/The_Operation_ARTEMIS _in_ the_Democratic_Republic_of_Congo (Downloaded: 29.03.2017) (As well as based on statements of Colonel János Tomolya.)

[6] UN: Operation Artemis. The lessons of the Interim Emergency International Force. http:// pbpu.unlb.org/PBPS/Library/Artemis.pdf (Downloaded: 29.03.2017)

[7] EEAS: EU Support to AMIS (Darfur). www.eeas.europa.eu/csdp/missions-and-operations/ eu-support-amis-darfur/index_en.htm (Downloaded: 29.03.2017)

[8] BESENYŐ J.: The first military operation between the European Union and the African Union. The European advisors' role in Darfur. AARMS, 64 (2007), 771-784. www.zmne. hu/aarms/docs/Volume6/Issue4/pdf/18bese.pdf (Downloaded: 29.03.2017)

[9] MAYS, T. M.: Historical Dictionary of Multinational Peacekeeping. Lanham: Scarecrow Press, 2010.

[10] EEAS: EUSEC RD Congo. www.eeas.europa.eu/csdp/missions-and-operations/eusec-rdcongo/index_en.htm (Downloaded: 29.03.2017)

[11] BESENYŐ J.: Beszámoló a kongói EUSEC misszióról. Afrika Tanulmányok, II 4 (2008), 28-33. www.afrikatanulmanyok.hu/application/essay/734_1.pdf (Downloaded: 29.03.2017)

[12] BESENYŐ J.: Magyar Békefenntartók Afrikában. Budapest: Katonai Nemzetbiztonsági Szolgálat, 2013.

[13] ENGBERG, K.: The EU and Military Operations: A Comparative Analysis. London: Routledge, 2013.

[14] KOUTRAKOS, P.: The EU Common Security and Defence Policy. Oxford: Oxford University Press, 2013.

19 Loading professional duties with Hungarian officers cost less and their operational losses add up fewer than sending a greater amount of infantry personnel. 
[15] EEAS: EUFOR RD Congo. www.eeas.europa.eu/csdp/missions-and-operations/eufor-rdcongo/index_en.htm (Downloaded: 29.03.2017)

[16] TÜRKE, A. I.: Potsdam - Un QGM européen (III.) http://europavarietas.org/csdp/ csdpblog/potsdam_qg_europeen (Downloaded: 29.03.2017)

[17] KOOPS, J. A.: The European Union as an Integrative Power: Assessing the EU's "effective Multilateralism” with NATO and the United Nations. Brussel: Vubpress, 2011.

[18] EEAS: EUFOR Tchad/RCA. www.eeas.europa.eu/csdp/missions-and-operations/eufortchad-rca/index_en.htm (Downloaded: 29.03.2017)

[19] TÜRKE A. I.: Mont Valérien - Un QGM européen (II.) http://europavarietas.org/csdp/ csdpblog/mont_valerien (Downloaded: 29.03.2017)

[20] MARSAI V.: A szomáliai kalózok és az EU Atalanata-missziója. Nemzet és Biztonság, 44 (2011), 66-76.

[21] SOUFIS, E.: Case Study of European Union Antipiracy Operation "Naval Force Somalia": Successes, Failures and Lessons Learned for the Hellenic Navy. Monterey: Naval Postgraduate School, 2012. www.hsdl.org/?view\&did=726089 (Downloaded: 29.03.2017)

[22] BOWDEN, A. (ed.): The economic cost of Maritime Piracy. (One Earth Future Working Paper.) http://oceansbeyondpiracy.org/sites/default/files/attachments/The\%20 Economic\%20Cost\%20of\%20Piracy\%20Full\%20Report.pdf (Downloaded: 29.03.2017)

[23] MARSAI V.: Szomália és kalózai I. Haditechnika, XLV 3 (2011), 9-12.

[24] EEAS: Countering Piracy off the coast of Somalia. www.eeas.europa.eu/csdp/missionsand-operations/eu-navfor-somalia/index_en.htm (Downloaded: 29.03.2017)

[25] ISS: Seminar reports. Lessons from Atalanta and EO counter-piracy policies. www.iss. europa.eu/uploads/media/Atalanta_report.pdf (Downloaded: 29.03.2017)

[26] EEAS: Military training mission in Somalia (EUTM Somalia). www.eeas.europa.eu/csdp/ missions-and-operations/eutm-somalia/index_en.htm, (Downloaded: 29.03.2017)

[27] NILSSON, C., NORBERG, J.: European Union Training Mission Somalia, a Mission Assessment. FOI-R-3870-SE. 13.04.2014.

[28] BESENYŐ J.: Portré: Horváth Csaba Zsolt százados, EUTM Somalia. Afrika Tanulmányok, VI 3 (2012), 55-74.

[29] BRATTBERG, E.: Opportunities lost, opportunities seized: the Libya crisis as Europe's perfect storm. Brussels: European Policy Centre, 2011. www.epc.eu/documents/uploads/ pub_1310_opportunities_lost.pdf (Downloaded: 29.03.2017)

[30] HANSEN, L. K., NIELSEN, K. L.: EU Strategic Culture and the 2011 Libyan War. www.ecsa-c.ca/wp-content/uploads/2014/11/3A_Hansen-and-Nielsen.pdf (Downloaded: 29.03.2017)

[31] EEAS: EUFOR Libya. www.eeas.europa.eu/csdp/missions-and-operations/eufor-libya/ index_en.htm, (Downloaded: 29.03.2017)

[32] BESENYŐ J.: War at the background of Europe: The crisis of Mali. AARMS, 122 (2013), 247-271. http://uni-nke.hu/uploads/media_items/aarms-vol-12_-issue-2_-2013.original.pdf (Downloaded: 29.03.2017)

[33] EEAS: EUTM Mali. www.eeas.europa.eu/csdp/missions-and-operations/eutm-mali/index_ en.htm, (Downloaded: 29.03.2017)

[34] WIKLUND, C. H., SKEPPSTRÖM, E.: European Union Training Mission Mali - Challenges and Opportunities. Peace Operations Project, FOI Memo 4797. 
J. BESENYŐ: Hungarian Participation in the EU-Led African Military Operations

www.foi.se/Documents/European\%20Union\%20Training\%20Mission\%20Mali-\%20

Challenges\%20and\%20Opportunities.pdf (Downloaded: 29.03.2017)

[35] BESENYŐ J.: Magyar műveleti tapasztalatok Maliban. Honvédségi Szemle, 1422 (2014), 78-92. www.honvedelem.hu/container/files/attachments/42782/hsz20142.pdf (Downloaded: 29.03.2017)

[36] NIRMARK, A.: EUFOR RCA: EU force or farce? www.cidob.org/publicaciones/opinion/ europa/eufor_rca_eu_force_or_farce (Downloaded: 29.03.2017)

[37] EEAS: EUFOR RCA. www.eeas.europa.eu/csdp/missions-and-operations/eufor-rca/index_ en.htm (Downloaded: 29.03.2017)

[38] EEAS: EUMAM RCA. http://eeas.europa.eu/csdp/missions-and-operations/eumam-rca/ index_en.htm (Downloaded: 29.03.2017)

[39] Council Decision 2015/778 of 18 May 2015 on a European Union military operation in the Southern Central Mediterranean (EUNAVFOR MED). http://eur-lex.europa.eu/legalcontent/EN/TXT/?uri=CELEX\%3A32015D0778 (Downloaded: 29.03.2017)

[40] EEAS: European Union Naval Force - Mediterranean Operation Sophia. https:// eeas.europa.eu/sites/eeas/files/eunavfor_med_-_mission_14_february_2017_en.pdf (Downloaded: 29.03.2017)

[41] EEAS: EUNAVFOR MED: operation SOPHIA training ships San Giorgio and Rotterdam welcomes on board the Libyan trainees. https://eeas.europa.eu/headquarters/headquartershomepage/16066/eunavfor-med-operation-sophia-training-ships-san-giorgio-androtterdam-welcomes-board-libyan_fi (Downloaded: 29.03.2017)

[42] EUROPEAN COMMISSION: Infografika - Az EU földközi-tengeri műveletei 2016ban. www.consilium.europa.eu/hu/infographics/saving-lives-sea-november-2016/ (Downloaded: 29.03.2017)

[43] EEAS: EUNAVFOR MED activity update to 31 December 2016. https://eeas.europa. eu/csdp-missions-operations/eunavfor-med/3790/eunavfor-med-operation-sophia_en (Downloaded: 29.03.2017)

[44] EEAS: EUNAVFOR MED Op SOPHIA - Six Monthly Report 1 January-31 October 2016. Brussels: Council of the European Union, 2016. http://statewatch.org/news/2016/dec/eucouncil-eunavformed-jan-oct-2016-report-restricted.pdf (Downloaded: 29.03.2017)

[45] DÓRA L.: Magyar részvétel a mediterrán térségi múveletben. Honvédelem (online), 2015. 10. 20. https://honvedelem.hu/cikk/54195_magyar_reszvetel_a_mediterran_tersegi_ muveletben (Downloaded: 29.03.2017) 